\title{
RESIDUAL EFFECTS OF PESTICIDES IN PEACH ORCHARDS ON THE MAIZE WEEVIL Sitophilus zeamais (COLEOPTERA: CURCULIONIDAE) ${ }^{1}$
}

\author{
SANDRO DANIEL NÖRNBERG ${ }^{2}$, ANDERSON DIONEI GRÜTZMACHER $^{3}$, \\ DORI EDSON NAVA ${ }^{4}$, RICARDO ALEXANDRE VALGAS ${ }^{5}$, ÂNGELO LUIS OZELAME ${ }^{6}$
}

\begin{abstract}
The aim of this study was to evaluate the residual effect of pesticides sprayed on peach orchards on $S$. zeamais. The study consisted of two experiments, according to the method of pesticide application. For Experiment I, pesticides were directly sprayed on peach trees and in Experiment II, the application of pesticides was performed under laboratory conditions. In both Experiments, the effect of pesticides was assessed in laboratory through the release of ten weevils per peach fruit. The effect of treatments was assessed by variable number of surviving insects. The results for pesticides [a.i. ( $\mathrm{ml}$ or g.100L)] have shown that application of treatments in the field (Experiment I), malathion (200) presented persistence at 1DAT (Days after treatments spraying) and control higher than $80 \%$, and thiametoxan (30) up to 3 DAT, while for phosmet (200) and fenthion (100), the control percentage was over $70 \%$ at 1 DAT. Under laboratory conditions, the application of the same insecticides showed control of 100\% at 120 HAT (Hours after treatment application). In this context, the use of insecticides by spraying plants must be considered an alternative method for the control of $S$. zeamais in peach, being necessary to the development and adoption of new control tools for its management.
\end{abstract}

Termos para indexação: chemical control, insecticides, persistence, Prunus persica.

\section{EFEITO RESIDUAL DE AGROTÓXICOS APLICADOS NA CULTURA DO PESSEGUEIRO SOBRE O GORGULHO DO MILHO Sitophilus zeamais (COLEOPTERA: CURCULIONIDAE)}

\begin{abstract}
RESUMO - O objetivo do trabalho foi avaliar o efeito residual de agrotóxicos, registrados para o controle de pragas de frutíferas de clima temperado, para o controle de Sitophilus zeamais Motschulsky, 1855 (Coleoptera: Curculionidae) em pomares de pessegueiro. O trabalho consistiu de dois experimentos, sendo que no Experimento I, a pulverização dos agrotóxicos foi realizada nos pomares e no Experimento II foi realizado em laboratório. Em ambos os experimentos, a avaliação do efeito dos agrotóxicos foi realizada em laboratório, através da liberação de dez gorgulhos por fruto e as avaliações do efeito dos tratamentos foram mensuradas pela variável número de insetos sobreviventes. Os resultados para os inseticidas [i.a ( $\mathrm{mL}$ ou g.100L)] mostram que: com aplicação dos tratamentos em condições de campo (Experimento I), malationa (200) apresentou persistência a 1 DAT (dias após o tratamento) com controle superior a 80\%, e o tiametoxan (30) até 3 DAT, enquanto que fosmete (200) e fentiona (100) apresentaram controle superior a 70\% a 1 DAT. Em condições de aplicação dos tratamentos em laboratório, os mesmos inseticidas apresentaram eficiência de controle de $100 \%$ a 120 HAT (Horas Após o Tratamento). Neste contexto, a utilização de inseticidas por meio de pulverização das plantas deve ser tratada como uma medida alternativa de controle de $S$. zeamais na cultura do pessegueiro, sendo necessário o desenvolvimento e adoção de novas ferramentas de controle para o seu manejo.
\end{abstract}

Termos para indexação: controle químico, inseticidas, persistência, Prunus persica.

\footnotetext{
${ }^{1}$ Trabalho (073-15). Recebido em: 09-03-2015. Aceito para publicação em: 10-02-2016.

${ }^{2}$ Eng. Agr. Dr., Pós-doutorando, Depto. Fitossanidade/FAEM/UFPel, Pelotas-RS, Bolsista DOCFIX-FAPERGS/CAPES. E-mail: sandro_ufpel@hotmail.com

${ }^{3}$ Eng. Agr. Dr., Prof. Depto. Fitossanidade/FAEM/UFPel, Pelotas-RS, Bolsista PQ CNPq. E-mail: anderson.grutzmacher@pq.cnpq.br ${ }^{4}$ Eng. Agr. Dr., Pesquisador A, Embrapa Clima Temperado, Pelotas-RS, Bolsista PQ CNPq. E-mail: dori.edson-nava@embrapa.br ${ }^{5}$ Bach. Estatística, MSc., Pesquisador Embrapa Clima Temperado, Pelotas-RS, E-mail: ricardo.valgas@embrapa.br ${ }^{6}$ Eng. Agr. Analista no Instituto Mato-grossense de Economia Agropecuária (Imea), Cuiabá - MT. E-mail: angeloluisozelame@ hotmail.com
} 


\section{INTRODUCTION}

Maize weevil Sitophilus zeamais Motschulsky, 1855 (Coleoptera: Curculionidae) is a pest typical of stored grains, and maize kernels are its main hosts (LORINI, 1999). However, its migration to fruit orchards has been observed (BOTTON et al., 2005a).

In southern Brazil, maize weevils were observed in orchards causing damage to apple, peach and grape fruits (SALLES, 1998; BONETTI et al., 1999; BOTTON et al, 2005b; HICKEL; SCHUCK, 2005; NÖRNBERG et al, 2013).

In addition to direct damage by the feeding of $S$. zeamais through perforation of the skin and pulp of fruits, there is indirect damage resulting in brown rot, caused by the fungus Monilinia fructicola (Wint.) (Honey, 1928) (Helotialis: Sclerotiniaceae). Brown rot is the most important diseases of peach whose infection is facilited by damage to the skin of fruits (FORTES; MARTINS, 1998).

Whereas stored grains, where weevils are key pests, the use of insecticides has been a way of efficient control (LORINI, 1999; SANTOS et al., 2009), could also be used in orchards, as they are used in the management of most pests in peach orchards. (NAVA; BOTTON, 2010).

Previous laboratory studies have shown efficiency of insecticides based on trichlorfon, fenthion, chlorpyrifos, malathion, fenitrothion, and methidathion, as well as on new molecules such as thiamethoxam (AFONSO et al., 2005). In addition, insecticide dimethoate has been an alternative, which is used close to the harvest by peach growers due to its 3-day waiting period (LIMA et al., 2009), while insecticide based on azadirachtin has shown efficiency in the in the insect control in stored grains (NUKENINE et al., 2011).

These products could be used in the management of weevils in orchards, however, considering that the attack of $S$. zeamais is performed in the harvest periods in peach orchards (SALLES, 1998) and that insecticides used in previous bioassays (AFONSO et al., 2005) have waiting period ranging from 3 to 21 days (AGROFIT, 2014), it is necessary to know their persistence (residual effect) when applied in field conditions.

The aim of this study was to evaluate the residual effect of pesticides in peach orchards through field and laboratory tests on S. zeamais.

\section{MATERIAL AND METHODS}

A field experiment was conducted in the 2011/12 growing season in a commercial peach orchard Prunus persica (L.) Batsch, cv. Magno, $\left(32^{\circ}\right.$ $39^{\prime} 23^{\prime \prime} \mathrm{N}, 52^{\circ} 46^{\prime} 16^{\prime \prime} \mathrm{W}$ ) and $150 \mathrm{~m}$ altitude. The orchard was installed in 2001 with spacing of $1.5 \mathrm{x}$ $5 \mathrm{~m}$ and plants were conducted in pots. Management practices carried out in the orchard were according to technical recommendations for the culture.

Experiment I was conducted in a split-plot experimental design with two crossed factors: pesticides and period after application. The pesticides factor was composed of nine levels: thiamethoxam (30g i.a. $\left.100 \mathrm{~L}^{-1}\right)$; azadirachtin $\left(50 \mathrm{~mL} .100 \mathrm{~L}^{-1}\right)$; deltamethrin $\left(40 \mathrm{~mL} .100 \mathrm{~L}^{-1}\right)$; phosmet $(200 \mathrm{~g}$ i.a. 100 $\left.\mathrm{L}^{-1}\right)$; sulfur $\left(600 \mathrm{~g}\right.$ i.a. $\left.100 \mathrm{~L}^{-1}\right)$; fenthion $(100 \mathrm{~mL} .100$ $\left.\mathrm{L}^{-1}\right)$; malathion $\left(200 \mathrm{~mL} .100 \mathrm{~L}^{-1}\right)$; dimethoate $(80$ $\mathrm{mL} .100 \mathrm{~L}^{-1}$ ) and control (only water); and the time factor was composed of five levels: 1, 3, 5, 7 and 10 days (fruit collection times). Four plants per treatment and 20 fruits per plant were used, and each fruit was infested with ten insects.

The pesticides used are registered and indicated for the control of pests in temperate climate fruit trees (AGROFIT, 2014). Their application was carried out under field conditions, using a $\mathrm{CO}_{2}$ pressurized knapsack sprayer equipped with a cone type nozzle model JA-1,5 (Jacto ${ }^{\circledR} \mathrm{S} / \mathrm{A}$ ), calibrated to apply $600 \mathrm{~L}$ ha ${ }^{-1}$ spray mix (pesticide plus water) and the plants were sprayed to run-off point.

In pre-defined periods of $1,3,5,7$ and 10 days after spraying of treatments (DAT) 20 fruits were collected from each treatment and individualized in plastic containers $(300 \mathrm{ml})$, and sent to the laboratory, where ten adult $S$. zeamais insects were released on each fruit. The insects used were from the creation of laboratory maintenance, which began by collecting specimens in commercial peach orchards infested in the region of Pelotas, Brazil (NÖRNBERG et al., 2013). After a period of 48 hours (ensuring contact and / or feeding of insects on fruits), the mortality of insects was evaluated. Weevils aged 7-14 days obtained from the creation of laboratory maintenance were used $\left(25 \pm 2{ }^{\circ} \mathrm{C} ; 70 \pm 10 \% \mathrm{RH}\right.$; $14 \mathrm{~h}$ photoperiod).

Data obtained were analyzed for normality by the Shapiro-Wilk test, homoscedasticity by the Hartley test and the independence of residues was graphically checked. Later, they were submitted to analysis of variance. In case of significance, the effects of pesticides were analyzed using Tukey test $(p \leq 0.05)$ and the effects of time by a quadratic polynomial regression model, as follows: $y=a+b x$ 
$+\mathrm{cx}^{2}$ where $a$ : intercept or value of the function at the origin; $b$ : slope coefficient or curve and corresponds to the instantaneous rate of the function at the origin; $c$ : curvature coefficient; $x$ : time (days). All tests were performed at $5 \%$ probability. The efficacy ( $\%)$ of pesticides was calculate corrected by Abbott's formula (ABBOTT, 1925).

Experiment II was carried out at the same time, where peach fruits were collected from peach plants (free of pesticide applications), and sent to the laboratory, where they were submitted to application of test-products, being dipped in pesticide syrup for 10 seconds according to methodology used by Afonso et al. (2005).

After drying, fruits were individually placed into plastic containers $(300 \mathrm{ml})$ and kept in climatized rooms under the same conditions of evaluations in Experiment I. Evaluations of the number of surviving weevils in each treatment were performed at 24,48 , 72, 96 and 120 hours after treatment application (HAT).

The experimental design used in Experiment II was completely randomized, using ten fruits per treatment, each fruit infested by ten insects, considered as repetition, totaling ten replicates per treatment.

Data were conducted an analysis of variance and means were compared by the Tukey test at 5\% probability. To assess mortality over time, survival curves were constructed using the Kaplan-Meier estimator, considering as failure the time until the death of the insect and censure the time the insect survived up to the end of experimental evaluation (120h). Subsequently, the curves were compared them with one another using the log-rank test with $\mathrm{R}$ (R DEVELOPMENT CORE TEAM, 2011).

\section{RESULTS AND DISCUSSION}

In experiment I, there was a significant interaction among factors studied for the control of $S$. zeamais. Comparing the pesticide within each valuation day, higher mortality of $S$. zeamais was observed at 1 DAT when submitted to contact with thiamethoxam, phosmet, fenthion and maltiona compared to other pesticides. The other treatments stood at intermediate position or with lower controls, not significantly differing from the control (Table 1, Figure 1).

Peach fruits submitted to treatment in field conditions showed different behavior among treatments in the first evaluation, at $1 \mathrm{DAT}$, and over time, treatments tended to show similar behavior, not differing at $10 \mathrm{DAT}$, except for thiamethoxam
(Figure 1). At 1 DAT, a significant reduction in the number of surviving weevils was observed for thiamethoxam, malathion, fenthion and phosmet with control efficiency of $85.1 \%, 85.6 \%, 74.2 \%$ and $73.2 \%$, respectively, while at 10 DAT, the control efficiency of these insecticides reduced drastically to $53.2 \%, 6.1 \%, 9.2 \%$ and $5.1 \%$, respectively (Table 1 ).

In the evaluation at $3 \mathrm{DAT}$, there was an increase in the average number of surviving weevils in all treatments, reducing their control efficiency, with the exception of thiamethoxam, with control efficiency of $80 \%$ (Table 1). In subsequent evaluations at 5, 7 and 10 DAT, pesticides showed an increase in the average number of living weevils and control efficiency of less than $53.3 \%$ except for thiamethoxam, which showed control efficiency of $74.9 \%$ at 5 DAT and in subsequent assessments, 7 DAT and 10 DAT, control efficiency of 63.2 and $53.2 \%$, respectively (Table 1 ).

In Experiment II, it was observed that the estimated survival rate of weevils as a function of time generated the formation of two distinct groups of treatments according to the survival of weevils over the evaluation period. Insecticides phosmet, thiamethoxam, malathion and fenthion significantly differed from control in the number of surviving insects, showing higher mortality at the first evaluation (24h), while dimethoate, deltamethrin and azadirachtin showed low mortality of weevils in all evaluations, and did not significantly differed from control (water only) (Figure 2).

Based on the survival curves obtained, it was possible to observe that in the first evaluation 24 hours after treatment, thiamethoxam and malathion caused more than $90 \%$ mortality of S. zeamais, while fenthion and phosmet showed mortality of $57.6 \%$ and $73.7 \%$, respectively (Figure 2). In subsequent evaluations, malathion showed $100 \%$ mortality at 48 hours while thiamethoxam at $72 \mathrm{~h}$ and fenthion and phosmet at $96 \mathrm{~h}$. Other treatments, azadirachtina, deltamethrin, sulfur and dimethoate had the same behavior, and did not differ from control treatment when the survival of S. zeamais is up to $120 \mathrm{~h}$ (Figure 1).

Insecticides based on azadirachtin do not always cause rapid mortality, mainly because they act in the biology of insects, so that the insecticide could present some effect on weevils after $120 \mathrm{~h}$, which was the maximum evaluation time in this experiment.

The results show that organophosphate insecticides (except for dimethoate) and insecticides from the group of neonicotinoids, thiamethoxam, were those with the highest control efficiency (Tables 1 and 2). 
However, the results should be observed considering two aspects: the action of climatic factors and application of pesticides. In experiment I, treatments simulated application carried out in peach orchards and there was variation in climatic factors such as temperature and rainfall. In the experimental period, the average precipitation was $4.84 \mathrm{~mm}$ (with occurrence at 7 and 9 DAT), the average temperature was $25.33^{\circ} \mathrm{C}$ (minimum 20.9 and maximum $29.6^{\circ} \mathrm{C}$ ).

In Experiment II, treatments were carried out in laboratory, ensuring full coverage of fruits with uniform treatments and climate conditions without the action of rainfall. Temperature and rainfall are important climatic factors that should be considered, since as Wills and McDowell (1987), they have a direct effect on the degradation of the molecular structures of pesticides.

Insecticides from the group of pyrethroids and organophosphates are widely used in the management of $S$. zeamais in storage locations and have presented control efficiency (SANTOS et al., 2009). However, deltamethrin (pyrethroid) and dimethoate (organophosphate) were not efficient in the control of $S$. zeamais under the conditions of this study. This may be due to the characteristics of each test product, such as the formulation and inert compound, as the commercial products used in this study are recommended for pest management in temperate climate fruit trees, differing from commercial products used in stored grains (AGROFIT, 2014). Another aspect that should be considered is the occurrence of resistant populations due to the massive and intense use of these compounds to control weevils (RIBEIRO et al., 2003; FRAGOSO et al., 2005). Similar results were found by Afonso et al. (2005), who observed low control efficiency for deltamethrin in direct and residual contact experiments in laboratory.

Another aspect to be considered for insecticides, dimethoate and deltamethrin is the dosage used in this study, since it was based on recommendation for other pests, which may not be adequate to control $S$. zeamais. This hypothesis does not apply to organophosphate insecticides fenthion, phosmet and malathion, as the results in Experiment II (Figure 2) show that at 120 HAT, 100\% mortality occurred, and these results are corroborated by previous studies (AFONSO et al., 2005 ).

The control of major insect pests in peach orchards has yet been carried out with the use of organophosphates or pyrethroids applied in full coverage or in the form of toxic bait (HÄRTER et al., 2010; NAVA; BOTTON 2010). In peach production, fenthion has been used in orchards managed in the Conventional Production System and pesticides phosmet and malathion in the Integrated Peach Production System for the management of the South American fruit fly, Anastrepha fraterculus Wiedemann, 1830 (Diptera: Tephritidae). Fenthion has 21-day waiting period while phosmet and malathion have 7-day waiting period (AGROFIT, 2014), therefore, its use aimed at the management of other pests cannot be effective against $S$. zeamais, as it attacks the fruit only in the phenological stage (Maturity of fruit) close to harvest (SALLES, 1998; NÖRNBERG et al., 2013), which may explain the high incidence of this insect pest in peach orchards managed with these pesticides.

Our results make clear the need for monitoring orchards, which can be done with traps baited with maize kernels (NÖRNBERG et al., 2013), so that control measures such as the use of insecticides are carried out near the beginning of the attack, since the highest mortality rate was observed between 1 and 3 DAT (Table 1). However, grace period can impair their use when the attack starts in the pre-harvest period due to potential problems of pesticide residue in fruits (LIMA et al., 2009).

In this sense, insecticides with control efficiency at 1 and 3 DAT in this study can be considered unsuitable for use in the control of $S$. zeamais in total area application in peach orchards. Insecticide thiamethoxam tested in commercial formulation Actara ${ }^{\circledR} 250 \mathrm{WG}$, which has no record for peach production, was more persistent, with control above $50 \%$ at 10 DAT, however, the lack of information such as grace period, momentarily impairs its recommendation for the culture. The use of insecticides in total area spraying is not the only way to control pests in orchards. It is possible a selectively way, for example by the use of toxic baits such as the treatment carried out for fruit flies (HÄRTER et al., 2010 NAVA; BOTTON, 2010). However, specific research is required, considering the bio-ecology of the target insect.

Another aspect that should be considered is the product application technology to be used in order to reach the biological target $S$. zeamais, and for this, bioecological aspects of this insect such as the attack characteristic should be taken into consideration. Based on the fact that weevil searches for shelter mainly on the stalk region (SALLES, 1998), an alternative would be the application of insecticides at the time when the insect comes to the orchard or even in the period of longer activity, which can be performed by traps called PET and those baited with maize (HICKEL; SCHUCH, 2005; NÖRNBERG et al., 2013.). The flight activity of $S$. 
zeamais is reported to be higher in the afternoon between 03:00 pm and 05:00 pm, being influenced by environmental conditions, especially temperature (WILLIANS; FLOYD, 1970), which is important information for control through the use of insecticide with contact action.

Considering the results obtained, the use of insecticides by spraying plants should be treated as an alternative measure to control $S$. zeamais in peach orchards, requiring the search for pest management tools within a sustainable production context. However, in the absence of other available control methods and considering the economic aspects directly affected by damage caused by pests, the use of insecticides in toxic bait can be a great control strategy and according to the results observed in this study, insecticides thiamethoxam, fenthion, phosmet and malathion can be considered as potential use, requiring, however, further studies to evaluate possible repellent effect and their persistence, toxicity on the weevil and effect on non-target organisms when applied associated with attractive substances.

TABLE 1 - Average numbers of surviving and control efficacy (\%) of Sitophilus zeamais after exposed to field-aged residues of pesticides in peach fruits. Pelotas, 2011/12.

\begin{tabular}{|c|c|c|c|c|c|c|}
\hline \multirow{2}{*}{ Treatments } & \multirow{2}{*}{$\mathrm{DC}^{1}$} & \multicolumn{5}{|c|}{ Days after pesticides spraying } \\
\hline & & 1 & 3 & 5 & 7 & 10 \\
\hline Thiamethoxam & 30 & $\begin{array}{c}1.50 \mathrm{~d}^{2} \\
(85.1)^{3}\end{array}$ & $\begin{array}{l}2.05 \mathrm{~d} \\
(80.1)\end{array}$ & $\begin{array}{l}2.50 \mathrm{~d} \\
(74.9)\end{array}$ & $\begin{array}{l}3.55 \mathrm{c} \\
(63.2)\end{array}$ & $\begin{array}{l}4.70 \mathrm{~b} \\
(53.2)\end{array}$ \\
\hline Azadirachtin & 40 & $\begin{array}{l}9.15 \mathrm{a} \\
(5.2)\end{array}$ & $\begin{array}{l}8.75 \mathrm{ab} \\
(12.0)\end{array}$ & $\begin{array}{r}9.70 \mathrm{a} \\
(2.1)\end{array}$ & $\begin{array}{r}10.00 \mathrm{a} \\
(0.0)\end{array}$ & $\begin{array}{c}10.00 \mathrm{a} \\
(0.0)\end{array}$ \\
\hline Deltamethrin & 40 & $\begin{array}{l}8.80 \mathrm{ab} \\
(9.3)\end{array}$ & $\begin{array}{l}9.10 \mathrm{a} \\
(9.0)\end{array}$ & $\begin{array}{r}9.35 \mathrm{a} \\
(4.1)\end{array}$ & $\begin{array}{r}10.00 \mathrm{a} \\
(0.0)\end{array}$ & $\begin{array}{c}10.00 \mathrm{a} \\
(0.0)\end{array}$ \\
\hline Phosmet & 200 & $\begin{array}{l}2.45 d \\
(74.2)\end{array}$ & $\begin{array}{l}3.45 \mathrm{~d} \\
(65.0)\end{array}$ & $\begin{array}{l}6.75 b \\
(30.8)\end{array}$ & $\begin{array}{l}7.05 \mathrm{~b} \\
(26.8)\end{array}$ & $\begin{array}{l}8.85 a \\
(9.2)\end{array}$ \\
\hline Sulfur & 600 & $\begin{array}{l}7.50 \mathrm{~b} \\
(22.7)\end{array}$ & $\begin{array}{l}9.35 \mathrm{a} \\
(6.0)\end{array}$ & $\begin{array}{r}9.80 \mathrm{a} \\
(0.0)\end{array}$ & $\begin{array}{r}10.00 \mathrm{a} \\
(0.0)\end{array}$ & $\begin{array}{c}10.00 \mathrm{a} \\
(0.0)\end{array}$ \\
\hline Fenthion & 100 & $\begin{array}{l}2.60 \mathrm{~d} \\
(73.2)\end{array}$ & $\begin{array}{l}5.05 \mathrm{c} \\
(59.0)\end{array}$ & $\begin{array}{l}6.55 b \\
(32.7)\end{array}$ & $\begin{array}{l}7.25 b \\
(25.5)\end{array}$ & $\begin{array}{l}9.25 \mathrm{a} \\
(5.1)\end{array}$ \\
\hline Malathion & 200 & $\begin{array}{l}1.35 \mathrm{~d} \\
(85.6)\end{array}$ & $\begin{array}{c}2.70 \mathrm{~d} \\
(73.0)\end{array}$ & $\begin{array}{l}4.55 c \\
(53.3)\end{array}$ & $\begin{array}{l}7.95 \mathrm{~b} \\
(17.6)\end{array}$ & $\begin{array}{l}9.15 \mathrm{a} \\
(6.1)\end{array}$ \\
\hline Dimethoate & 80 & $\begin{array}{l}5.80 \mathrm{c} \\
(40.2)\end{array}$ & $\begin{array}{l}7.50 \mathrm{~b} \\
(25.0)\end{array}$ & $\begin{array}{r}9.40 \mathrm{a} \\
(4.1)\end{array}$ & $\begin{array}{c}10.00 \mathrm{a} \\
(0.0)\end{array}$ & $\begin{array}{l}10.00 \mathrm{a} \\
(0.0)\end{array}$ \\
\hline Control & - & $9.65 \mathrm{a}$ & $9.75 \mathrm{a}$ & $9.75 \mathrm{a}$ & $9.65 \mathrm{a}$ & $9.35 \mathrm{a}$ \\
\hline
\end{tabular}

${ }^{1} \mathrm{DC}=$ Dose of the commercial formulation $\left(\mathrm{g}\right.$ or $\left.\mathrm{mL} .100 \mathrm{~L}^{-1}\right)$; Mortality were corrected with Abbott's formula (ABBOTT, 1925) Means followed by the same letter in the columns do not differ significantly by Tukey test $(\mathrm{p} \leq 0,05)$, comparing pesticides in each fruit collection time. 


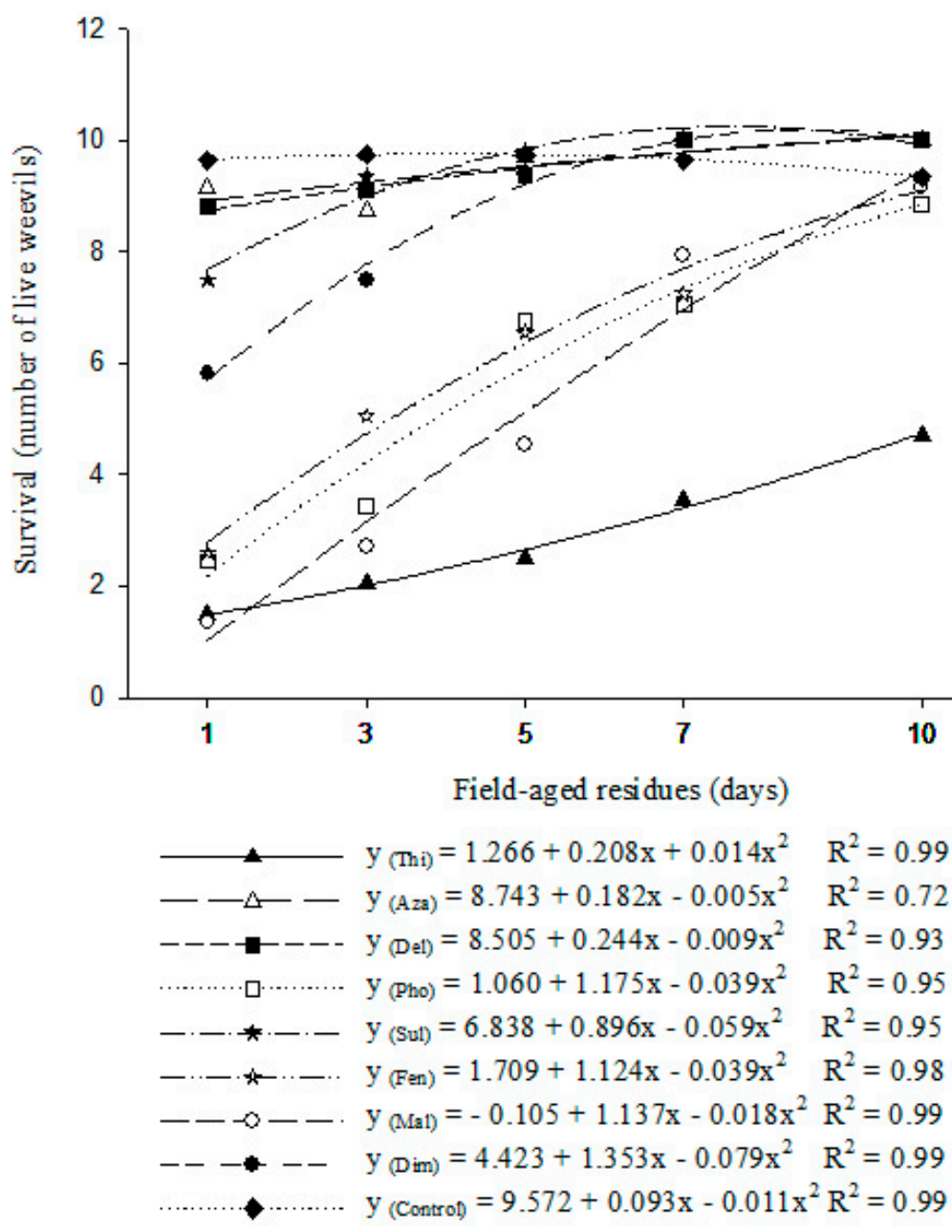

FIGURE 1 - Survival of Sitophilus zeamais exposed to pesticides at 1, 3, 5, 7 and 10 days after application in peach orchard. Thiamethoxam (Thi); azadirachtin (Aza); deltamethrin (Del); phosmet (Pho); sulfur (Sul); fenthion (Fen); malathion (Mal); dimethoate (Dim); and control (Control). Pelotas, 2011/12. 


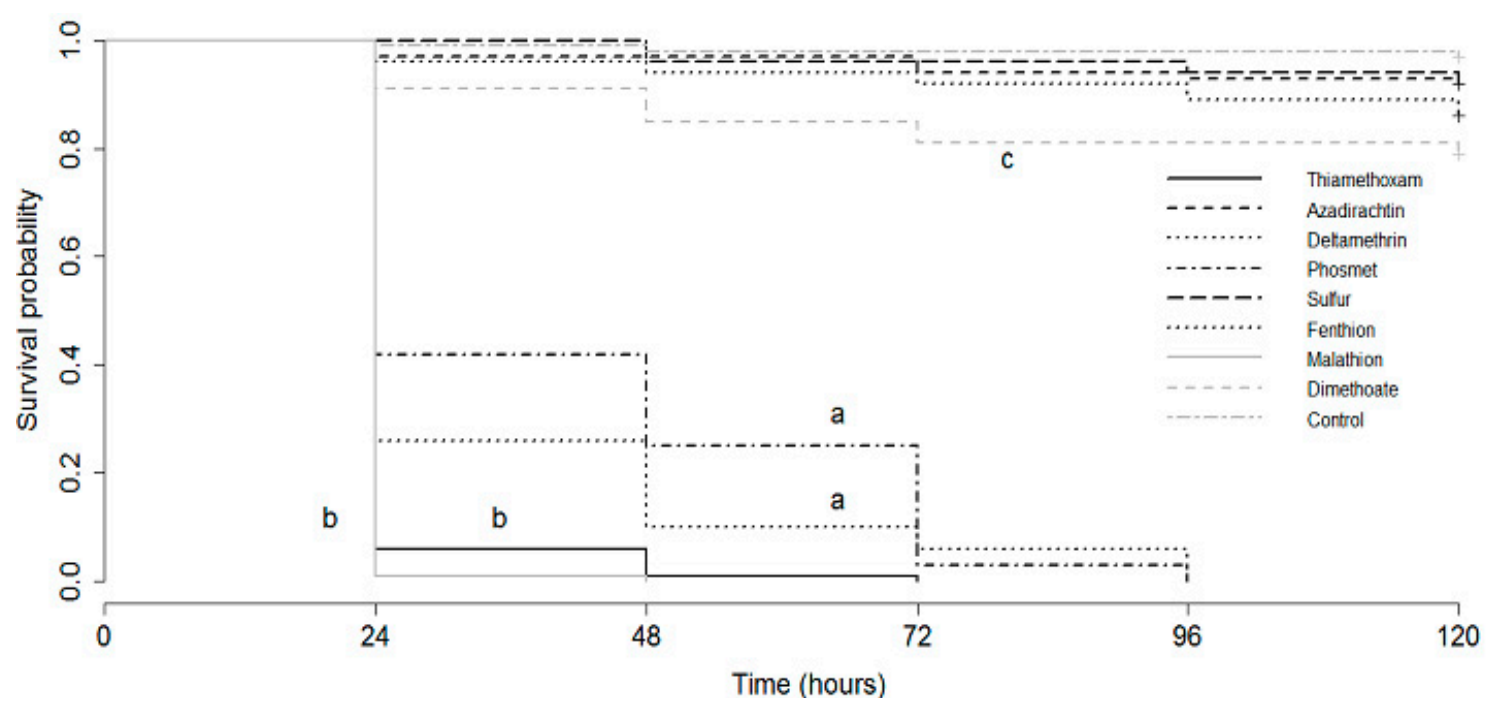

FIGURE 2- Survival curves of Sitophilus zeamais exposed to peach fruits treated with pesticides on laboratory trials. Temperature: $25 \pm 2{ }^{\circ} \mathrm{C}$; RH: $70 \pm 10 \%$; a photoperiod of $14: 10(\mathrm{~L}: \mathrm{D}) \mathrm{h}$. Curves followed by different letters differ statistically from each other, by the log Rank test (P 0.05).

\section{CONCLUSIONS}

The application of pesticides in field conditions shows that at 1 DAT, malathion caused mortality above $80 \%$, while insecticides phosmet and fenthion caused mortality of $S$. zeamais above $70 \%$. Up to 3 DAT, insecticide thiamethoxam caused mortality above $80 \%$. Under laboratory conditions, the same insecticides caused mortality of $100 \%$ up to 120 hours after the application of treatments.

\section{ACKNOWLEDGMENTS}

To CNPq (National Council for Scientific and Technological Development) for the granting of doctoral scholarships, research productivity and financial support. To FAPERGS / CAPES for granting postdoctoral DOCFIX scholarship.

\section{REFERENCES}

ABBOTT, W.S. A method of computing the effectiveness of insecticide. Journal of Economic Entomology, Manasha, v.18, n.2, p.265-267, 1925.

AFONSO, A.P.S.; FARIA, J.L; BOTTON, M.; LOECK, A.E. Controle de Sitophilus zeamais Mots., 1855 (Coleoptera: Curculionidae) em fruteiras temperadas. Ciência Rural, Santa Maria, v.35, n.2, p.253-258, 2005.

AGROFIT: Sistema de agrotóxicos fitossanitários. Disponível em: < $\underline{\text { http://agrofit.agricultura.gov. }}$ br/agrofit_cons/principal_agrofit_cons $>$. Online. Acesso em: 20 jul. 2014.

BONETTI, J.I.S.; RIBEIRO, L.G.; KATSURAYAMA, Y. Manual de identificação de doenças e pragas da macieira. Florianópolis: Epagri, 1999. 149p.

BOTTON, M.; LORINI, I.; LOECK, A.E.; AFONSO, A.P.S. O gorgulho do milho Sitophilus zeamais como praga em frutíferas de clima temperado. Bento Gonçalves: Embrapa Uva e Vinho, 2005a. 7p. (Circular Técnica, 58) 
BOTTON, M.; LORINI, I.; AFONSO, A.P.S. Ocorrência de Sitophilus zeamais (Coleoptera: Curculionidae) danificando a cultura da videira no Rio Grande do Sul. Neotropical Entomology, Londrina, v.34, n.2, p.355-356, 2005 b.

FORTES, J.F.; MARTINS, O.M. Sintomatologia e controle das principais doenças. In: MEDEIROS, C.A.B.; RASEIRA, M.C. A cultura do pessegueiro. Brasília: Embrapa-CPACT, 1998. p.243-264.

FRAGOSO, D.B.; GUEDES, R.N.C.; PETERNELLI, L.A. Developmental rates and population growth of insecticide-resistant and susceptible populations of Sitophilus zeamais. Journal of Stored Products Research, Oxford, v. 41, n.3, p.271-281, 2005.

HÄRTER, W.; GRÜTZMACHER, A.D.; NAVA, D.E.; GONÇALVES, R.S.; BOTTON, M. Isca tóxica e disrupção sexual no controle da mosca-da-fruta sul-americana e da mariposa-oriental em pessegueiro. Pesquisa Agropecuária Brasileira, Brasília, v.45, n.3, p.229-235, 2010.

HICKEL, E.R.; SCHUCK, E. Infestação e danos do gorgulho-do-milho em videira. Revista Agropecuária Catarinense, Florianópolis, v.18, n.1, p.49-52, 2005.

LIMA, C.A.B.; GRÜTZMACHER, D.D.; KRÜGER, L.R.; GRÜTZMACHER, A.D. Diagnóstico da exposição ocupacional a agrotóxicos na principal região produtora de pêssego para a indústria do Brasil. Ciência Rural, Santa Maria, v.39, n.3, p.900903, 2009.

LORINI, I. Pragas de grãos armazenados. Passo Fundo: Embrapa Trigo, 1999. 60p.

NAVA, D.E.; BOTTON, M. Bioecologia e controle de Anastrepha fraterculus e Ceratitis capitata em pessegueiro. Pelotas: Embrapa Clima Temperado, 2010. 29p. (Documentos, 315).

NÖRNBERG, S.D.; NAVA, D.E.; GRÜTZMACHER, A.D.; BENTO, J.M.S.; OZELAME, A.L.; HÜBNER, L.K. Flutuação populacional e distribuição de Sitophilus zeamais em pomares de pessegueiro e macieira. Pesquisa Agropecuária Brasileira, Brasília, v.48, n.4, p.358-364, 2013.
NUKENINE, E.N.; TOFEL, H.K.; ADLER, C. Comparative efficacy of NeemAzal and local botanicals derived from Azadirachta indica and Plectranthus glandulosus against Sitophilus zeamais on maize. Journal of Pest Science, Berlin, v.84, n.4, p.479-486, 2011.

R DEVELOPMENT CORE TEAM. R: a language and environment for statistical computing. Vienna: $\mathrm{R}$ Foundation for Statistical Computing, 2011

RIBEIRO, B.M.; GUEDES, R.N.C.; OLIVEIRA, E.E.; SANTOS, J.P. Insecticide resistance and synergism in Brazilian populations of Sitophilus zeamais (Coleoptera: Curculionidae). Journal of Stored Products Research, Oxford, v.39, n.1, p.21-31, 2003.

SALLES, L.A.B. Principais pragas e seu controle. In: MEDEIROS, C.A.B.; RASEIRA, M.C. A cultura do pessegueiro. Brasília: Embrapa-CPACT, 1998. p.206-242.

SANTOS, J.C.; FARONI, L.R.D.; SIMÕES, R.O.; PIMENTEL, M.A.G.; SOUSA, A.H. Toxicidade de inseticidas piretróides e organofosforados para populações brasileiras de Sitophilus zeamais (Coleoptera: Curculionidae). Bioscience Journal, Uberlândia, v.25, n.6, p.75-81, 2009.

WILLIANS, R.N.; FLOYD, E.H. Flight habits of the maize weevil, Sitophilus zeamais. Journal of Economic Entomology, Manasha, v.63, n.5, p.15851588,1970 .

WILlS, G.H.; McDOWELL, L.L. Pesticide persistence on foliage. Reviews of Environmental Contamination and Toxicology, Summerfield, v.100, p.23-73, 1987. 